\title{
NUTRITIONAL DIAGNOSIS IN HYBRID COCONUT CULTIVATED IN NORTHEASTERN BRAZIL THROUGH DIAGNOSIS AND RECOMMENDATION INTEGRATED SYSTEM (DRIS) ${ }^{1}$
}

\author{
EDUARDO CÉZAR MEDEIROS SALDANHA ${ }^{2}$, MÁRIO LOPES DA SILVA JUNIOR ${ }^{3}$, \\ PAULO MANOEL PONTES LINS ${ }^{3}$, SAMUEL CHRISTIAN COHEN FARIAS ${ }^{4}$, \\ PAULO GLULHERME SALVADOR WADT ${ }^{5}$
}

\begin{abstract}
The assessment of the nutritional status of plants by leaf diagnosis such as the Diagnosis and Recommendation Integrated System (DRIS) has stood out among traditional methods of interpreting the results of plant tissue analysis. For coconut, nutritional monitoring through foliar analysis has been pointed as an efficient method for fertilizer recommendation, and the results have been traditionally interpreted using the critical level of sufficiency ranges criteria. The aim of this study was to evaluate the nutritional status and establish nutritional standards for the cultivation of hybrid coconut in the municipality of Moju, Pará, using DRIS. The leaf analysis and productivity results of 134 observations for the period 2001-2011 were used to form the database. The most common deficiencies found were lack of $\mathrm{K}$, and possibly excess of $\mathrm{Mg}$. The order of nutrient limitation was $\mathrm{K}>\mathrm{P}>\mathrm{Ca}>\mathrm{Fe}>\mathrm{N}>\mathrm{O}>\mathrm{B}>\mathrm{Zn}>\mathrm{Cu}>\mathrm{Mn}>\mathrm{Mg}$. Ca, Fe and $\mathrm{K}$ nutrients are more likely to positively respond to fertilization, since $\mathrm{Mg}, \mathrm{Cu}$ and $\mathrm{Mn}$ were diagnosed as having the greatest likelihood of negative response to fertilization. It was also found that $\mathrm{N}$ and $\mathrm{P}$ are elements that are in the best nutritional balance condition. Regression equations for the relationship between nutrient content in hybrid coconut leaves and its DRIS indexes were adjusted, which allowed establishing nutrient reference values based on DRIS.
\end{abstract}

Index terms: Leaf analysis, Reference Standards, DRIS indexes.

\section{DIAGNOSE NUTRICIONAL EM COQUEIRO HÍBRIDO CULTIVADO NA REGIÃO NORTE DO BRASIL DO ESTADO DO PARÁ POR MEIO DO SISTEMA INTEGRADO DE DIAGNOSE E RECOMENDAÇÃO}

RESUMO - A avaliação do estado nutricional de plantas por meio da diagnose foliar, como o Sistema Integrado de Diagnose e Recomendação (DRIS), vem destacando-se dos métodos tradicionais de interpretação dos resultados da análise de tecido vegetal. Para o coqueiro, o acompanhamento nutricional por meio de análise foliar é apontado como método eficiente para a recomendação de adubação, e os resultados têm sido tradicionalmente interpretados com a utilização do critério do nível crítico e das faixas de suficiência. Os objetivos deste trabalho foram avaliar o estado nutricional e estabelecer padrões nutricionais para a cultura do coqueiro híbrido, utilizando o método DRIS. O trabalho foi realizado em área comercial de coqueiros no município de Moju-PA. Utilizou-se, para formar o banco de dados, de resultados de análise foliar e de produtividade de 134 observações referentes ao período de 2001 a 2011. Verificou-se deficiências mais frequentes para o elemento $\mathrm{K}$, e possivelmente excessos para elemento $\mathrm{Mg}$. A ordem de limitação nutricional foi $\mathrm{K}>\mathrm{P}>\mathrm{Ca}>\mathrm{Fe}>\mathrm{N}>\mathrm{S}>\mathrm{B}>\mathrm{Zn}>\mathrm{Cu}>\mathrm{Mn}>\mathrm{Mg}$. Os nutrientes $\mathrm{Ca}$, $\mathrm{K}$ e $\mathrm{Fe}$ apresentaram maior probabilidade de resposta positiva a adubação, já os nutrientes $\mathrm{Mg}, \mathrm{Cu}$ e $\mathrm{Mn}$ foram diagnosticados como os de maior probabilidade de resposta negativa à adubação. Verificou-se, também, que os nutrientes $\mathrm{N} \mathrm{e}$ P apresentaram a melhor condição de equilíbrio nutricional. Foram ajustadas equações de regressão para a relação entre os teores de nutrientes em folhas de coqueiro híbrido e os respectivos índices DRIS, o que possibilitou estabelecer valores de referências nutricionais, com base no método DRIS.

Termos para indexação: diagnose foliar, padrões de referência, índices DRIS.

\footnotetext{
${ }^{1}$ (Paper 164-15). Received June 23, 2015. Accepted April 04, 2016. Thesis of the first author

2Professor at UFRA - Capitão Poço Campus. Email: ecmsaldanha@yahoo.com.br

${ }^{3}$ Professor at UFRA - Belém Campus. Email: mario.silva@ufra.edu.br

${ }^{4}$ Head of Research and Development of Company Sococo - Agroindústria da Amazônia. Email: paulom@sococo.com.br

${ }^{5}$ Agronomic Engineer at Company Sococo - Agroindústria da Amazônia. Email: samuelc@sococo.com.br

${ }^{6}$ Researcher at Embrapa Rondônia. Email: wadt@dris.com.br
} 


\section{INTRODUCTION}

The nutritional diagnosis in cultivated plants has evolved to used in the interpretation of the nutritional contents in plant tissues, methods that relate nutrient contents to each other, such as the Diagnosis and Recommendation Integrated System (DRIS) (BEAULFILS, 1973), replacing interpretations by traditional methods such as the critical level and the sufficiency range, which evaluate each nutrient in isolation. Nutritional diagnosis is an important step in detecting possible deficiencies and assisting in fertilization programs. In the case of coconut cultivation, nutritional status monitoring through leaf tissue analysis was pointed out by Sobral and Santos (1987) as an auxiliary tool for fertilization recommendation.

Critical level and sufficiency range methods are generally the most used criteria for the evaluation and interpretation of the nutritional status of plants and have been applied in several annual or perennial crops (PRADO et al., 2008). This method has the advantage of being able to directly interpret nutrient content by comparing the content in the sample with the reference value (critical level) or with the sufficiency range.

However, Wadt and Dias (2014) argue that DRIS may have as advantage, over conventional methods, the possibility of minimizing the effects of uncontrolled factors on variations in dry matter concentration and / or dilution rates. This would be due to the fact that the DRIS method calculates an index for each nutrient, which is obtained from relationships among nutrient accumulation rates in the evaluated tissue.

Knowing the relative accumulation rates, normalized in relation to the same relations of plants considered healthy and productive, it is then possible to infer about the ordering of nutrients in relation to their balance in the sampled tissue. Thus, in the interpretation of DRIS indexes, negative index indicates that the nutrient is below the optimal level, positive index indicates that the nutrient is above the optimal level, while the DRIS index of a nutrient close to or equal to zero indicates that this nutrient would be in balance with the other nutrients (BEAUFILS, 1973).

In short, for being relative indexes, the diagnosis results can be ordered in an increasing order, which is called the order of nutrient limitation (WADT, DIAS, 2014). In this case, the first nutrient ordered corresponds to the nutrient diagnosed as the greatest limitation for deficiency and would be demanded in greater amount by the plant, and the last nutrient, the one that would be in excess. Nutrients with DRIS index close to zero, or with values equal to zero, would be considered nutritionally balanced (BEAULFIS, 1973).

In the specific case of hybrid coconut plantations in the state of Pará, the leaf analyses results have traditionally been interpreted using the critical level and sufficiency ranges criterion, but there is a great disadvantage and assertiveness fragility. In turn, the use of the DRIS enables nutritional standards to be obtained from commercial crop data and / or fertilization trials, thus facilitating the attainment of reference values that may be applicable for new materials and new management conditions (SALDANHA et al., 2015).

However, it is important to highlight that the set of plants to be used for the definition of nutritional standards represents, as much as possible, all interactions that may exist among factors that determine the nutritional status of crops (RODRIGUEZ; RODRIGUEZ, 2000); therefore, the possible number of variability of the cultivation conditions of the species to be evaluated should be used, unlike the work of Santos et al. (2004), who proposed DRIS standards exclusively by taking leaf samples from a single planting area and at different times of the year (six collections per year).

In this sense, the aim of this work was to establish nutritional standards for the Critical Level method and DRIS standards for hybrid coconut and to use the DRIS standards to evaluate the nutritional status for this crop in the northeastern region of the state of Pará.

\section{MATERIAL AND METHODS}

The study was carried out in a commercial coconut plantation located in the municipality of Moju, state of Pará $\left(02^{\circ} 07^{\prime} 00\right.$ "S and $48^{\circ} 22^{\prime} 30^{\prime}$ " $\mathrm{W})$. The predominant soils found in this region correspond to Yellow Latosols (MANCIOT, 1979). The region has a monsoon tropical climate, according to the Köppen classification, characterized as rainy tropical, without seasonal thermal variation and with annual average rainfall of 2,500 $\mathrm{mm}$.

Data from the nutritional contents of 134 leaf samples and crop productivity of hybrid coconut collected from 2001 to 2011 were used to compose a nutritional monitoring database. The database was formed from coconut leaf samples collected in preselected orchards, which, when grouped together, formed the leaf diagnosis units.

Leaf samples were composed of six leaflets collected from the central part of leaf 14, three 
on each side, removing $10 \mathrm{~cm}$ from the central part. Leaflets were cleaned with cotton soaked in deionized water, removing the central rib and edges of the limbus, and dried in an air forced circulation oven at $75^{\circ} \mathrm{C}$ for 48 hours. Nutrients $\mathrm{N}, \mathrm{P}, \mathrm{K}, \mathrm{Ca}, \mathrm{Mg}$, $\mathrm{S}, \mathrm{B}, \mathrm{Cu}, \mathrm{Fe}, \mathrm{Mn}$ and $\mathrm{Zn}$ were determined according to methodology proposed by Malavolta et al. (1997). In all orchards, usual practices of phytotechnical management that involved the control of spontaneous herbs through the application of herbicide, cleaning of plants and biological control practices of the main pests of coconut crop were carried out.

The database was divided into two subpopulations (Reference Population - PR, and Non - Reference Population - PNR), as a function of fruit yield (fruits per plant per year). Reference Populations (PR) were considered as those that presented productivity above 130 fruits / plant $^{-1}$ year ${ }^{1}$, according to productivity standards established by literature (DALLEMOLE et al., 2008; LINS et al., 2003; MOHANDAS , 2012), totaling 30 cases.
Although the number of cases used in this work is small, it was higher that the sampling performed by Santos et al. (2004) also with coconut trees in the northern region of Rio de Janeiro. The average fruit yield in the region where data were collected was approximately 130 fruits / plant $^{-1}$ year $^{-1}$

The DRIS standards for hybrid coconut cultivation were obtained from the set of cases of the reference population, calculating the relationships in the form of quotient between the nutritional contents of $\mathrm{N}, \mathrm{P}, \mathrm{K}, \mathrm{Ca}, \mathrm{Mg}, \mathrm{S}, \mathrm{B}, \mathrm{Cu}, \mathrm{Mn}$ and $\mathrm{Zn}$, both in the direct and in the inverse form, obtaining for these relations the mean statistics, standard deviations and variation coefficients, as recommended by Beaufils (1973) (BEAUFILS, 1973).

In order to calculate the DRIS indexes of the 134 leaf samples, the DRIS standards obtained as described in this work were used in the calculation of the DRIS index, that with the highest value for the F test, for the distribution of the relations between reference subpopulations and non-reference subpopulation (JONES, 1981):

\section{Indice DRIS $X=\frac{f\left(\frac{X}{A}\right)+f\left(\frac{X}{B}\right)+\cdots+f\left(\frac{X}{N}\right)-f\left(\frac{A}{X}\right)-f\left(\frac{B}{X}\right)-\ldots-f\left(\frac{N}{X}\right)}{Z}$}

where: $\mathrm{X}=$ nutrient under study; $\mathrm{A}, \mathrm{B}, \mathrm{C}$ ..., $\mathrm{N}=$ nutrients that appear in the numerator or denominator of the relationships with element $\mathrm{X}$; Z $=$ number of functions involved in the calculation of the index.

For the calculation of the DRIS functions, Jones's formula (1981) was adopted:

$$
f\left(\frac{X}{A}\right)=\frac{\left[M\left(\frac{X}{A}\right)-m\left(\frac{x}{a}\right) \cdot k\right.}{s\left(\frac{x}{a}\right)}
$$

where: $\mathrm{M}(\mathrm{X} / \mathrm{A})=$ value of the nutritional relation $\mathrm{X} / \mathrm{A}$ in the study population; $\mathrm{M}(\mathrm{x} / \mathrm{a})=$ value of the nutritional relation $\mathrm{X} / \mathrm{A}$ in the reference population; $S(x / a)=$ standard deviation of the nutritional relation in the reference population; $\mathrm{K}=$ constant, adopted as a scaling factor to facilitate the reading of the DRIS indexes in whole values, being arbitrarily adopted the value 10 .

The nutritional balance index (IBN) was calculated by the sum of all the indexes involved, in a module, according to the following expression:
For the interpretation of the DRIS indexes, the standard procedure proposed by Beaufils (1973) was first used, in which the nutritional limitation order was determined by ordering the index of smallest value (more limiting by deficiency) to the one of the greatest value (more limiting by excess). The second interpretation procedure used was to determine the percentage of total limitation occurrence, computing as limiting all nutrients with negative indexes of each sample (LEANDRO, 1998).

The percentage of occurrence in the first, second, and third orders, corresponding to the first, second, and third indexes, respectively, to the index from the lowest value to the highest value, provided that negative, in each sample was also obtained. This criterion was adopted with the purpose of identifying the three most limiting nutrients in each evaluated orchard.

The database was grouped into six categories regarding orchard productivity, considering the number of fruits / plant $^{-1}$ year- ${ }^{1}$ (FPA): $<50 ; 51-70$; $71-90 ; 91-110 ; 110-130$ and $>130$ as grouping criterion. The productivity classes were adopted to

\section{IBN $-[$ I DRIS N $]+[$ I DRIS P $]+[$ [IDRIS K $]+[$ I DRISCG $]+[$ [I DRIS Mg $]+[$ [ DRIS S $]$ $+[$ I DRIS B $]+[$ I DRIS Cu $]+[$ I DRIS Fe $]+[$ [I DRIS Mn] $+[$ I DRIS Zn $]$}


differentiate the reference population from those of non-reference, and to divide the non-reference population into five subclasses, each with a productivity interval of 20 FPA within each group of orchard, the mean DRIS index of nutrients, IBN, was calculated and the order of nutritional limitation was defined based on the direct interpretation (negative index, index equal to zero and positive index).

Linear regression analysis was used to establish models between DRIS indexes and leaf nutrient contents, and the optimal value for the nutritional content was then mathematically obtained by regression based on the premise that the optimum content is equal to the value corresponding to the nutritional balance, that is, when the nutrient DRIS index equals zero (WALWORTH; SUMNER, 1987), as also adopted by other authors (WADT et al., 1998; SILVA, 2001; REIS JÚNIOR et al., 2002; REIS JÚNIOR;MONNERAT, 2003;KURIHARA, 2004). Regression analysis was also performed between the Nutritional Balance Index (IBN) and agricultural productivity.

Calculations related to DRIS standards, DRIS indexes, IBN and IBNm were performed using Microsoft Excel ${ }^{\circledR}$ spreadsheets, and regression analyses were performed using the Assistat ${ }^{\circledR}$ software (SILVA; AZEVEDO, 2009).

\section{RESULTS AND DISCUSSION}

The statistics for each bivariate relation, among the evaluated nutrients, were composed of the set of DRIS norms for coconut tree (Table 1).

In general, the highest variation coefficients were associated to relationships involving micronutrients, as verified in rice crop (WADT et al., 2013).

For fruit productivity averages, the variation coefficient (VC) was lower in the reference group, compared to the non-reference group, with values ranging from 3.1 to $27.7 \%$, respectively (Table 2), which indicates lower amplitude in the nutritional contents for orchards considered as reference.

Lower VC value indicates greater sensitivity to relationship involving the nutrient in pointing out nutritional deficiency (ROCHA et al., 2007; SANTANA et al., 2008).

Data presented in Table 3 were interpreted according to procedure of Leandro (1998), considering the percentage of total limitation occurrence in the first, second and third orders of limitation.

The order of nutritional limitation, from the percentage of total limitation occurrence, was: $\mathrm{K}>$
$\mathrm{P}>\mathrm{Ca}>\mathrm{Fe}>\mathrm{N}>\mathrm{S}>\mathrm{B}>\mathrm{Zn}>\mathrm{Cu}>\mathrm{Mn}>\mathrm{Mg} . \mathrm{K}$ and $\mathrm{Ca}$, highlighting as the nutrients with the highest frequency of occurrence in the first, second and third orders, while P presented low occurrence in the first, second and third order classes. This means that the imbalance associated with $\mathrm{P}$ is probably due to its imbalance related to other nutrients, while for $\mathrm{K}$ and $\mathrm{Ca}$, the probability of true deficiency is more relevant. In productivities above 70 fruits / plant $^{-1}$ year ${ }^{-1}$, nutrients $\mathrm{K}$ and $\mathrm{Ca}$ were those with the highest frequency of occurrence of negative DRIS index (Table 4), while $\mathrm{Mn}$ and $\mathrm{Mg}$ were the nutrients with the highest occurrence in excess, regardless of productivity class. Nutritional deficiencies of potassium indicated by the order of nutritional limitation in the classes of highest productivities can be explained by the higher demand of this nutrient in more productive plants; once in coconut plantations, potassium deficiencies are more common (SOBRAL, 1998) because the amounts removed are high due to the fact that the plant develops continuously. Plants that comprise the class of highest productivity $\left(>130\right.$ fruits / plant $^{-1}$ year ${ }^{-1}$ ) had lower average IBN, indicating that they would be more nutritionally balanced. The sum of the absolute values of the DRIS indexes composes the mean nutritional balance index (IBNm), which expresses the nutritional balance of the sampled orchard. Santos et al. (2004) also found lower IBN in higher productivity classes with dwarf coconut, when evaluating nutritional status through DRIS, corroborating values observed in this study.

Greater dependence indicates that the variation in nutrient content explains most (above $80 \%$ ) of the variability observed in the DRIS indexes, while lower dependence $(<50 \%)$ indicates that the nutrient balance would be responsible for explaining variations in DRIS indexes. Thus, positive and significant correlations $(\mathrm{p}<0.01)$ between nutrient concentrations and respective DRIS indexes were verified for all nutrients (Table 5). In the case of micronutrients $\mathrm{B}, \mathrm{Cu}, \mathrm{Fe}$ and $\mathrm{Mn}$, the determination coefficients of regression equations $\left(\mathrm{R}^{2}>80\right)$ suggest dependence between the DRIS index and the concentration of the respective nutrient in the plant leaf. For $\mathrm{N}$ and $\mathrm{P}$, there was no dependence $\left(\mathrm{R}^{2}<50\right)$. For nutrients $\mathrm{K}, \mathrm{Ca}, \mathrm{Mg}, \mathrm{S}$ and $\mathrm{Zn}$, the degree of dependence was intermediate $\left(\mathrm{R}^{2}\right.$ between 50 and 80 ). Therefore, in this context, the balance of micronutrients (except $\mathrm{Zn}$ ) was dependent on the availability of the nutrient in the plant, and the $\mathrm{N}$ and $\mathrm{P}$ balance was dependent on the physiological balance of nutrients in orchards.

Serra et al. (2012) found a strong positive correlation between DRIS indexes and leaf macro 
and micronutrient contents in work with cotton crop, with emphasis on the higher determination coefficient values obtained with micronutrients, similar to results found in this work.

Thus, as in this work $\left(\mathrm{R}^{2}=0.35\right)$, other authors (SERRA et al., 2012; GUINDANI et al., 2009) find smaller determination coefficient values for $\mathrm{N}\left(\mathrm{R}^{2}\right.$ $=0.49$ and $\mathrm{R}^{2}=0.20$, respectively) in work with cotton and rice crops, respectively. Low relationship between DRIS index and nitrogen concentration was also observed for several perennial crops, such as apple (NACHTIGALL, 2004), citrus (SALVO, 2001) and coffee (REIS JÚNIOR et al., 2002).

Linear regressions adjusted for the relationship between nutrient contents and DRIS indexes (Table 5) allowed defining the optimum levels for each nutrient (Table 6).
It was observed that the nutritional balance values at DRIS and the leaf critical $\mathrm{N}$ and $\mathrm{P}$ levels used for nutritional monitoring in the commercial plantation area were close to each other, with differences smaller than $10 \%$. For the other nutrients, the values found were significantly different, highlighting $\mathrm{Ca}, \mathrm{Mg}, \mathrm{Cu}, \mathrm{Fe}, \mathrm{Mn}$ and $\mathrm{Zn}$, whose differences among values found were higher than $30 \%$. The observed differences may be indicative of the need to recalculate the values of leaf critical levels adopted for hybrid coconut cultivation in the state of Pará, and the levels defined by the DRIS Nutritional Balance Point can be used as comparison parameters in future works aimed at calibrating foliar contents for the definition of critical levels.

TABLE 1 - DRIS standards - mean, standard deviation (SD), variation coefficient (VC\%) in the reference population for the relationships among nutrients in hybrid coconut cultivated in the municipality of Moju-PA.

\begin{tabular}{cccccccccccc}
\hline Relationship & Mean & SD & VC & Relationship & Mean & SD & VC & Relationship & Mean & SD & VC \\
\hline $\mathrm{P} / \mathrm{N}$ & 0.072 & 0.005 & 6.27 & $\mathrm{Mg} / \mathrm{K}$ & 0.070 & 0.005 & 6.43 & $\mathrm{~B} / \mathrm{S}$ & 12.560 & 3.486 & 27.75 \\
$\mathrm{~K} / \mathrm{N}$ & 0.750 & 0.135 & 17.96 & $\mathrm{~S} / \mathrm{K}$ & 0.084 & 0.024 & 28.21 & $\mathrm{~S} / \mathrm{Cu}$ & 0.340 & 0.131 & 38.41 \\
$\mathrm{Ca} / \mathrm{N}$ & 0.190 & 0.034 & 17.78 & $\mathrm{~B} / \mathrm{K}$ & 1.059 & 0.417 & 39.34 & $\mathrm{Fe} / \mathrm{S}$ & 93.510 & 20.525 & 21.95 \\
$\mathrm{Mg} / \mathrm{N}$ & 0.070 & 0.009 & 12.14 & $\mathrm{~K} / \mathrm{Cu}$ & 4.100 & 1.265 & 30.85 & $\mathrm{Mn} / \mathrm{S}$ & 87.670 & 22.010 & 25.1 \\
$\mathrm{~S} / \mathrm{N}$ & 0.061 & 0.012 & 19.46 & $\mathrm{Fe} / \mathrm{K}$ & 7.870 & 2.561 & 32.53 & $\mathrm{Zn} / \mathrm{S}$ & 18.270 & 2.383 & 13.04 \\
$\mathrm{~B} / \mathrm{N}$ & 0.760 & 0.226 & 29.75 & $\mathrm{Mn} / \mathrm{K}$ & 7.150 & 1.833 & 25.63 & $\mathrm{~B} / \mathrm{Cu}$ & 4.024 & 1.137 & 28.27 \\
$\mathrm{Cu} / \mathrm{N}$ & 0.200 & 0.067 & 33.7 & $\mathrm{Zn} / \mathrm{K}$ & 1.510 & 0.327 & 21.65 & $\mathrm{Fe} / \mathrm{B}$ & 8.065 & 3.068 & 38.05 \\
$\mathrm{Fe} / \mathrm{N}$ & 5.720 & 1.644 & 28.73 & $\mathrm{Mg} / \mathrm{Ca}$ & 0.370 & 0.072 & 19.46 & $\mathrm{Mn} / \mathrm{B}$ & 7.360 & 2.350 & 31.92 \\
$\mathrm{Mn} / \mathrm{N}$ & 5.230 & 1.113 & 21.28 & $\mathrm{Ca} / \mathrm{S}$ & 2.910 & 0.843 & 28.95 & $\mathrm{Zn} / \mathrm{B}$ & 1.530 & 0.376 & 24.6 \\
$\mathrm{Zn} / \mathrm{N}$ & 1.100 & 0.169 & 15.4 & $\mathrm{~B} / \mathrm{Ca}$ & 3.960 & 1.281 & 32.34 & $\mathrm{Cu} / \mathrm{Fe}$ & 0.038 & 0.017 & 43.63 \\
$\mathrm{P} / \mathrm{K}$ & 0.099 & 0.021 & 21.47 & $\mathrm{Cu} / \mathrm{Ca}$ & 1.035 & 0.102 & 37.04 & $\mathrm{Mn} / \mathrm{Cu}$ & 28.410 & 9.104 & 32.00 \\
$\mathrm{P} / \mathrm{Ca}$ & 0.376 & 0.064 & 17.00 & $\mathrm{Fe} / \mathrm{Ca}$ & 29.410 & 7.667 & 26 & $\mathrm{Zn} / \mathrm{Cu}$ & 5.990 & 1.690 & 28.20 \\
$\mathrm{Mg} / \mathrm{P}$ & 0.980 & 0.112 & 11.44 & $\mathrm{Mn} / \mathrm{Ca}$ & 27.210 & 6.399 & 23.51 & $\mathrm{Mn} / \mathrm{Fe}$ & 0.998 & 0.377 & 37.74 \\
$\mathrm{~S} / \mathrm{P}$ & 0.850 & 0.131 & 15.35 & $\mathrm{Zn} / \mathrm{Ca}$ & 5.700 & 0.809 & 14.19 & $\mathrm{Zn} / \mathrm{Fe}$ & 0.210 & 0.071 & 33.57 \\
$\mathrm{~B} / \mathrm{P}$ & 10.630 & 3.108 & 29.23 & $\mathrm{Mg} / \mathrm{S}$ & 1.180 & 0.223 & 18.89 & $\mathrm{Mn} / \mathrm{Zn}$ & 4.790 & 0.990 & 20.67 \\
$\mathrm{Cu} / \mathrm{P}$ & 2.790 & 0.944 & 33.83 & $\mathrm{Mg} / \mathrm{B}$ & 0.100 & 0.036 & 35.8 & & & & \\
$\mathrm{Fe} / \mathrm{P}$ & 78.950 & 19.368 & 24.54 & $\mathrm{Mg} / \mathrm{Cu}$ & 0.390 & 0.146 & 37.41 & & & & \\
$\mathrm{Mn} / \mathrm{P}$ & 73.110 & 15.568 & 21.29 & $\mathrm{Fe} / \mathrm{Mg}$ & 81.450 & 23.000 & 28.23 & & & & \\
$\mathrm{Zn} / \mathrm{P}$ & 15.370 & 2.194 & 14.27 & $\mathrm{Mn} / \mathrm{Mg}$ & 74.560 & 15.673 & 21 & & & & \\
$\mathrm{~K} / \mathrm{Ca}$ & 3.900 & 0.859 & 22.00 & $\mathrm{Mg} / \mathrm{Zn}$ & 0.065 & 0.011 & 16.92 & & & & \\
\hline & & & & & & & & & & & \\
& & & & & & & & & \\
& & & & & & & \\
\end{tabular}


TABLE 2-Average, minimum, maximum values and variation coefficient (VC) for productivity (number of coconut $/$ plant $^{-1}$ year $^{-1}$ ) and leaf nutrient contents in hybrid coconut cultivated in Moju-PA from 2001 to 2011 in reference $(\mathrm{N}=30)$ and non-reference $(\mathrm{n}=104)$ subpopulations.

\begin{tabular}{|c|c|c|c|c|c|c|c|c|}
\hline \multirow[t]{2}{*}{ Variable } & \multicolumn{4}{|c|}{ Reference Population } & \multicolumn{4}{|c|}{ Non-reference Population } \\
\hline & Mean & Minimum & Maximum & $\mathrm{VC}(\%)$ & Mean & Minimum & Maximum & $\mathrm{VC}(\%)$ \\
\hline $\begin{array}{l}\text { Coconut / } \\
\text { plant }^{-1} \text { year }^{-1}\end{array}$ & 136.7 & 130.7 & 147.2 & 3.1 & 106 & 9.8 & 117.9 & 27.7 \\
\hline $\mathrm{N}\left(\mathrm{g} \mathrm{kg}^{-1)}\right.$ & 21.1 & 16.8 & 25.2 & 13.5 & 20.1 & 3.4 & 30.1 & 15.5 \\
\hline$P\left(\mathrm{~g} \mathrm{~kg}^{-1}\right)$ & 1.5 & 1.2 & 1.8 & 14.7 & 1.3 & 0.9 & 2.0 & 12.6 \\
\hline $\mathrm{K}\left(\mathrm{g} \mathrm{kg}^{-1}\right)$ & 15.5 & 10.2 & 20.1 & 17.5 & 13.9 & 9.4 & 24.9 & 16.4 \\
\hline $\mathrm{Ca}\left(\mathrm{g} \mathrm{kg}^{-1}\right)$ & 4.2 & 2.8 & 4.9 & 14.1 & 3.5 & 2.1 & 6.5 & 25.8 \\
\hline $\operatorname{Mg}\left(\mathrm{g} \mathrm{kg}^{-1}\right)$ & 1.4 & 1.1 & 1.9 & 16.5 & 1.4 & 0.9 & 2.1 & 17.3 \\
\hline $\mathrm{S}\left(\mathrm{g} \mathrm{kg}^{-1)}\right.$ & 1.2 & 1.0 & 1.7 & 19.8 & 1.26 & 0.6 & 2.5 & 25.3 \\
\hline $\mathrm{B}\left(\mathrm{mg} \mathrm{kg}^{-1)}\right.$ & 16 & 9 & 22 & 25 & 16 & 5.0 & 36 & 33 \\
\hline $\mathrm{Cu}\left(\mathrm{mg} \mathrm{kg}^{-1)}\right.$ & 4 & 3 & 5 & 25 & 4 & 2 & 8 & 30 \\
\hline $\mathrm{Fe}\left(\mathrm{mg} \mathrm{kg}^{-1)}\right.$ & 125 & 62 & 190 & 30 & 108 & 47 & 287 & 42 \\
\hline $\mathrm{Mn}\left(\mathrm{mg} \mathrm{kg}^{-1)}\right.$ & 109 & 70 & 157 & 18 & 120 & 55 & 228 & 30 \\
\hline $\mathrm{Zn}\left(\mathrm{mg} \mathrm{kg}^{-1)}\right.$ & 23 & 20 & 27 & 9 & 23 & 15 & 44 & 19 \\
\hline
\end{tabular}

TABLE 3-Percentage of occurrence of the most limiting nutrients diagnosed by the DRIS indexes for hybrid coconut cultivation in 134 leaf samples.

\begin{tabular}{ccccc}
\hline & \multicolumn{4}{c}{ \% of occurrence $^{1}$} \\
\hline Nutrient & Total (\%) & $\mathbf{1}^{\text {st }}$ order & $\mathbf{2}^{\text {nd }}$ order & $\mathbf{3}^{\text {rd }}$ order \\
\hline $\mathrm{N}$ & 49 & 3 & 7 & 7 \\
$\mathrm{P}$ & 66 & 4 & 9 & 15 \\
$\mathrm{~K}$ & 84 & 21 & 24 & 19 \\
$\mathrm{Ca}$ & 59 & 26 & 10 & 8 \\
$\mathrm{Mg}$ & 25 & 1 & 6 & 2 \\
$\mathrm{~S}$ & 48 & 6 & 13 & 10 \\
$\mathrm{~B}$ & 45 & 10 & 10 & 7 \\
$\mathrm{Cu}$ & 39 & 10 & 4 & 5 \\
$\mathrm{Fe}$ & 58 & 16 & 10 & 7 \\
$\mathrm{Mn}$ & 35 & 1 & 4 & 5 \\
$\mathrm{Zn}$ & 42 & 0 & 0 & 5 \\
\hline
\end{tabular}

TABLE 4 - Mean DRIS indexes, mean nutritional balance index (IBNm) and order of nutrient limitation in hybrid coconut orchards in the municipality of Moju-PA in six productivity classes.

\begin{tabular}{|c|c|c|c|c|c|c|c|c|c|c|c|c|c|c|}
\hline \multicolumn{3}{|c|}{ Productivity $^{1}$} & \multicolumn{9}{|c|}{ DRIS $m$ index } & \multicolumn{2}{|c|}{ IBN m } & \multirow[t]{2}{*}{ Order of limitation } \\
\hline & $\mathbf{n}$ & $\mathbf{N}$ & $\mathbf{P}$ & $\mathbf{K}$ & $\mathbf{C a}$ & Mg & $\mathbf{S}$ & $\mathbf{B}$ & $\mathrm{Cu}$ & $\mathbf{F e}$ & Mn & $\mathbf{Z n}$ & & \\
\hline 50 & 10 & -1 & -4 & -8 & -10 & 17 & -4 & 1 & 0 & -11 & 21 & 0 & 77 & $>\mathrm{Mg}>\mathrm{Mn}$ \\
\hline $51-70$ & 8 & -2 & 0 & -7 & -5 & 7 & -2 & -1 & 0 & -9 & 16 & 4 & 53 & $\mathrm{Fe}>\mathrm{K}>\mathrm{Ca}>\mathrm{S}=\mathrm{N}$ \\
\hline $71-90$ & 9 & -1 & -8 & -17 & -12 & 11 & -2 & 2 & 0 & -4 & 21 & 9 & 87 & $\mathrm{~K}>\mathrm{Ca}>\mathrm{P}>\mathrm{Fe}>\mathrm{S}>1$ \\
\hline $91-110$ & 31 & -2 & -3 & -9 & -8 & 8 & 4 & 0 & 6 & -4 & 7 & 1 & 52 & $\mathrm{~K}>\mathrm{Ca}>\mathrm{Fe}>\mathrm{P}>\mathrm{N}>\mathrm{B}>\mathrm{Zn}>\mathrm{S}>\mathrm{Cu}>\mathrm{Mn}>\mathrm{Mg}$ \\
\hline $110-130$ & 46 & -1 & -2 & -12 & -8 & 13 & -2 & 1 & 1 & 1 & 3 & 3 & 47 & $\mathrm{~K}>\mathrm{Ca}>\mathrm{P}=\mathrm{S}>\mathrm{N}>\mathrm{B}=\mathrm{Cu}=\mathrm{Fe}>\mathrm{Mn}=\mathrm{Zn}>\mathrm{Mg}$ \\
\hline$>130$ & 30 & 1 & -2 & -8 & -3 & 4 & 0 & 2 & 4 & 0 & 2 & 1 & 27 & $\mathrm{~K}>\mathrm{Ca}>\mathrm{P}>\mathrm{S}=\mathrm{Fe}>\mathrm{N}=\mathrm{Zn}>\mathrm{B}=\mathrm{Mn}>\mathrm{Cu}>\mathrm{Mg}$ \\
\hline
\end{tabular}

${ }^{1}$ fruits / plant / year

$\mathrm{n}$ - number of observations per class to obtain the mean 
TABLE 5 - Statistical model of relationships between DRIS index and leaf nutrient concentration in leaf samples of 134 hybrid coconut trees from 2001 to 2011.

\begin{tabular}{cllc}
\hline \multicolumn{2}{c}{ Variable } & \multicolumn{1}{c}{ Statistical model } & $\mathbf{R}^{2}$ \\
\hline Independent & \multicolumn{1}{c}{ Dependent } & \multicolumn{1}{c}{ } & $0.35^{* *}$ \\
\hline $\mathrm{N}^{1}$ & DRIS N & DRIS N $=1.41 \mathrm{~N}-28.55$ & $0.43^{* *}$ \\
$\mathrm{P}$ & DRIS P & DRIS P $=23.84 \mathrm{P}-36.02$ & $0.64^{* *}$ \\
$\mathrm{~K}$ & DRIS K & DRIS K $=3.32 \mathrm{~K}-56.96$ & $0.78^{* *}$ \\
$\mathrm{Ca}$ & DRIS Ca & DRIS Ca $=13.48 \mathrm{Ca}-55.26$ & $0.68^{* *}$ \\
$\mathrm{Mg}$ & DRIS Mg & DRIS Mg $=44.96 \mathrm{Mg}-55.78$ & $0.77^{* *}$ \\
$\mathrm{~S}$ & DRIS S & DRIS S $=37.87 \mathrm{~S}-47.98$ & $0.90^{* *}$ \\
$\mathrm{~B}$ & DRIS B & DRIS B $=2.33 \mathrm{~B}-35.62$ & $0.84^{* *}$ \\
$\mathrm{Cu}$ & DRIS Cu & DRIS Cu $=9.77 \mathrm{Cu}-37.94$ & $0.90^{* *}$ \\
$\mathrm{Fe}$ & DRIS Fe & DRIS Fe $=0.28 \mathrm{Fe}-32.33$ & $0.84^{* *}$ \\
$\mathrm{Mn}$ & DRIS Mn & DRIS Mn $=0.38 \mathrm{Mn}-38.48$ & $0.62^{* *}$ \\
$\mathrm{Zn}$ & DRIS Zn & DRIS Zn $=1.95 \mathrm{Zn}-41.41$ &
\end{tabular}

** significant by $\mathrm{F}$ test at $1 \%$ probability

${ }^{1}$ macronutrients $\left(\mathrm{g} \mathrm{kg}^{-1}\right)$ and micronutrients $\left(\mathrm{mg} \mathrm{kg}^{-1}\right)$

TABLE 6 - Nutritional balance at DRIS and leaf critical level for nutrients in the hybrid coconut crop in leaf samples of 134 hybrid coconut trees from 2001 to 2011.

\begin{tabular}{lcc}
\hline Nutrient & Nutritional balance at DRIS ${ }^{\mathbf{1}}$ & Critical level of the region $^{2}$ \\
\hline $\mathrm{N}\left(\mathrm{g} \mathrm{kg}^{-1}\right)$ & 20.2 & 22.0 \\
$\mathrm{P}\left(\mathrm{g} \mathrm{kg}^{-1}\right)$ & 1.5 & 1.4 \\
$\mathrm{~K}\left(\mathrm{~g} \mathrm{~kg}^{-1}\right)$ & 17.2 & 14.0 \\
$\mathrm{Ca}\left(\mathrm{g} \mathrm{kg}^{-1}\right)$ & 4.1 & 3.0 \\
$\mathrm{Mg}\left(\mathrm{g} \mathrm{kg}^{-1}\right)$ & 1.2 & 2.2 \\
$\mathrm{~S}\left(\mathrm{~g} \mathrm{~kg}^{-1}\right)$ & 1.3 & 1.5 \\
$\mathrm{~B}\left(\mathrm{mg} \mathrm{kg}^{-1}\right)$ & 15 & 20 \\
$\mathrm{Cu}\left(\mathrm{mg} \mathrm{kg}^{-1}\right)$ & 4 & 10 \\
$\mathrm{Fe}\left(\mathrm{mg} \mathrm{kg}^{-1}\right)$ & 115 & 40 \\
$\mathrm{Mn}\left(\mathrm{mg} \mathrm{kg}^{-1}\right)$ & 101 & 70 \\
$\mathrm{Zn}\left(\mathrm{mg} \mathrm{kg}^{-1}\right)$ & 21 & 8 \\
\hline
\end{tabular}

${ }^{1}$ Nutrient concentration in leaves of nutritionally balanced plants

${ }^{2}$ Critical foliar levels adopted for interpretation of foliar analysis Lins, 2003 


\section{CONCLUSION}

The nutritional diagnoses carried out using DRIS indicated $\mathrm{K}$ as the most limiting element due to deficiency and the most limiting ones due to excess. Mn for orchards with average productivity lower than 90 fruits / plant $^{-1}$ year ${ }^{-1}$ and $\mathrm{Mg}$ for orchards with average productivity above 90 fruits / plant $^{-1}$ year ${ }^{-1}$

The foliar contents considered optimal by means of DRIS indicated large divergences for nutrients $\mathrm{Ca}, \mathrm{Mg}, \mathrm{Cu}, \mathrm{Fe}, \mathrm{Mn}$ and $\mathrm{Zn}$, when compared to those adopted as a regional reference by means of critical levels, showing the need for validation through experimental works.

The values considered optimal for leaf contents in hybrid coconut were $20.2 ; 1.5 ; 17.2 ; 4.1$; 1.2 and $1.3 \mathrm{~g} \mathrm{~kg}^{-1}$, respectively for $\mathrm{N}, \mathrm{P}, \mathrm{K}, \mathrm{Ca}, \mathrm{Mg}$ and $\mathrm{S}$, and $15 ; 4 ; 115 ; 101$ and $21 \mathrm{mg} \mathrm{kg}^{-1}$ for $\mathrm{B}, \mathrm{Cu}$, $\mathrm{Fe} \mathrm{Mn}$ and $\mathrm{Zn}$.

\section{ACKNOWLEDGMENTS}

The authors would like to thank SOCOCO S / A Agroindústria da Amazônia, for the technical and operational support for the conduction of this study, as well as to Agronomist, PhD. Paulo Manoel Pontes Lins, Research and Development Director of Sococo Group for the support and data availability.

\section{REFERENCES}

BEAUFILS, E.R. Diagnosis and Recommendation Integrated System (DRIS): a general scheme for experimentation and calibration based on principles develop from research in plant nutrition. Soil Science Bulletin, Pietermaritzburg, n. 1, p.132, 1973.

DALLEMOLE, D; LINS, P; SANTANA, A.C. Análise de investimento de coqueiral híbrido PB 121 para produção de coco seco. Revista de Estudos Sociais, Cuiabá, v.10. n.20, p.2, 2008.

GUINDANI，R.R.H.P; ANGHINONI，I.; NACHTIGALL, G.R. DRIS na avaliação do estado nutricional do arroz irrigado por inundação Revista Brasileira de Ciência do Solo, Viçosa, MG, v.33, p.109-118, 2009.
JONES, C.A. Proposed modifications of the diagnosis and recommendation integrated system (DRIS) for interpreting plant analysis. Communications Soil Science Plant Analysis, New York, v.12, p.785794, 1981.

KURIHARA, C.H. Demanda de nutrientes pela soja e diagnose de seu estado nutricional. 2004. Tese (Doutorado) - Universidade Federal de Viçosa, Viçosa, 2004.

LEANDRO, W.M. Sistema integrado de diagnose recomendação (DRIS) para a cultura da soja (Glycine maxL. Merril) na região de Rio VerdeGO. 1998. 157 f. Tese (Doutorado) - Escola de Agronomia e Engenharia de Alimentos, Universidade Federal de Goiás, Goiânia, 1998.

LINS, P.M.P; NETO, J.T.F.; MULLER, A.A Avaliação de híbridos de coqueiro (cocos nucifera l.) para produção de frutos e de albúmen sólido fresco. Revista Brasileira de Fruticultura, Jaboticabal, v.25, n.3, p.468-470, 2003.

MALAVOLTA, E.; VITTI, G.C.; OLIVEIRA, S.A. Avaliação do estado nutricional das plantas. 2. ed. rev. atual. Piracicaba: POTAFOS, 1997. 319p.

MANCIOT, R. Instalação de uma plantação de coqueiros híbridos no Brasil. Moju-Pará: Sococo, 1979. 90 p. (Relatório de atividades).

MOHANDAS, S. Effect of NPK fertilizer levels on mineral nutrition and yield of hybrid (Tall $\mathrm{x}$ Dwarf) coconut. Madras Agricultural Journal, Coimbatore, v.99, n.1-3, p.87-91, 2012.

NACHTIGALL, G.M.; DECHEN, A.R. Dris norms for evaluating the nutritional state of Apple tree. Scientia Agrícola, Piracicaba, v.64. n.3, p.282-287, 2007.

PRADO, R. de M; ROZANE, D.E; VALE, D.W. do; CORREIA, M.A.R; SOUZA, H.A. de. Nutrição de plantas: diagnose foliar em grandes culturas. Jaboticabal: FCAV, Capes/Fundunesp, 2008. 301 p.

REIS JÚNIOR, R.A.; MONNERAT, P.H. DRIS norms validation for sugarcane crop. Pesquisa Agropecuária Brasileira, Brasília, DF, v.38, p.379385, 2003. 
REIS JUNIOR, R.A; CORRÊA, J.B; CARVALHO, J.G; GUIMARÃES, P.T.G. Estabelecimento de normas DRIS para o cafeeiro no Sul de Minas Gerais: $1^{\mathrm{a}}$ aproximação. Ciência Agrotecnologia, Lavras, v. 26, n. 2, p. 269-282, 2002.

ROCHA, A.C. da; LEANDRO, W.M; ROCHA, A.O; SANTANA, J. das G; ANDRADE, J.W. de S. Normas DRIS para cultura do milho semeado em espaçamento reduzido na região de Hidrolândia, GO, Brasil. Bioscience Journal, Washington, v.23, p.50-60, 2007.

RODRIGUEZ, O.; RODRIGUEZ, V. Desarrollo, determinación e interpretación de normas DRIS para el diagnóstico nutricional en plantas. Una revision. Revista de la Facultad Agronomia, Luz, v.17, p. 449-470, 2000.

SANTANA, J. das G.; LEANDRO, W.M.; NAVES, R.V.; CUNHA, P.P. da. Normas DRIS para interpretação de análises de folha e solo, em laranjeira pêra, na região central de Goiás. Pesquisa Agropecuária Tropical, Goiania, v.38, p.109-117, 2008.

SALDANHA, E.C.M.; SILVA JUNIOR, M.L.; OKUMURA, R.S.; WADT, P.G.S. Normas DRIS para a cultura do coqueiro híbrido no Estado do Pará. Revista Caatinga, Mossoró, v.28, p.99-109, 2015.

SANTOS, A.L. dos; MONNERAT, P.H.; CARVALHO, A.J.C.C. Estabelecimento de normas DRIS para o diagnóstico nutricional do coqueiroanão verde na região Norte Fluminense. Revista Brasileira de Fruticultura, Jaboticabal, v.26, n.2, p.330-334, 2004.

SERRA, A. P; MARCHETTI, M. E; ROJAS, E. P; VITORINO, A. C. T. Beaufils ranges to assess the cotton nutrient status in the southern region of Mato Grosso. Revista Brasileira de Ciência do Solo, Viçosa, MG, v.36, p.171- 181, 2012.

SILVA, F.A.S; AZEVEDO, C.A.V. Principal components analysis in the software Assistat Statistical Attendance. In: WORLD CONGRESS ON COMPUTERS IN AGRICULTURE, 7., 2009, Reno. Proceedings... St Joseph: American Society of Agricultural and Biological Engineers, 2009.
SILVA, G.G.C. Diagnose nutricional do eucalipto pelo DRIS, M-DRIS e CND. 2001. 132 f. Dissertação (Mestrado) - Universidade Federal de Viçosa, Viçosa, 2001. (4) (Corrigir p. 12 linha 32 de SALVO, 2001 para SILVA, 2001.

SOBRAL, L.F. Nutrição e adubação do coqueiro. In: FERREIRA, J.M.S.; WARWICK, D.R.N.; SIQUEIRA, L.A. A cultura do coqueiro no Brasil. 2. ed. Brasília: Embrapa-SPI; Aracaju: Embrapa / CPATC, 1998. p.129-157.

SOBRAL, L.F; SANTOS, Z.G. Sistema de recomendações de fertilizantes para o coqueiro (Cocos nucifera L.) com base na análise foliar. Brasília, DF: EMBRAPA-DDT, 1987. 23 p. (Documentos, 7).

WADT, P.G.S; NOVAIS, R.F; ALVAREZ V, V.H; FONSECA, S.; BARROS, N.F. Valores de referência para macronutrientes em eucalipto obtidos pelos métodos Dris e chance matemática. Revista Brasileira de Ciência do Solo, Viçosa, MG, v.22, p.685-692,1998a.

WADT, P.G.S.; DIAS, J.R.M. Premissas para a aplicação do DRIS em espécies florestais e palmeiras. In: PRADO, R.M.; WADT, P.G.S. (Org.). Nutrição e adubação de espécies florestais e palmeiras. Jaboticabal: FUNEP, 2014. v.1, p. 277-298.

WADT, P.G.S.; ANGHINONI, I.; GUINDANI, R.H.P.; LIMA, A.S.T.; PUGA, A.P.; SILVA, G.S.; PRADO, R.M. Padrões nutricionais para lavouras arrozeiras irrigadas por inundação pelos métodos da CND e Chance Matemática. Revista Brasileira de Ciência do Solo, Viçosa, MG, v.37, p.145-156, 2013.

WALWORTH, J.L; SUMNER, M.E. The diagnosis and recommendation integrated system (DRIS). Advances in Soil Science, New York, v.6, p.149188, 1987. 